Article

\title{
At a Crossroads: Investigating Automobility and Its Implications for Local Urban Transport Policy Design
}

\author{
Mike Hynes \\ School of Political Science \& Sociology, National University of Ireland Galway, Room 323, 2nd Floor, \\ Áras Moyola, Galway H91 TK33, Ireland; mike.hynes@nuigalway.ie \\ Academic Editor: Michael Peter Smith \\ Received: 10 January 2017; Accepted: 2 May 2017; Published: 5 May 2017
}

\begin{abstract}
More people than ever before are living in urban settlements, increasing competition for living space, employment, food, water, and energy. Urbanisation poses many challenges, most notably meeting the basic health and well-being needs of inhabitants. One of the key challenges faced is the increase in transport-related energy consumption and its negative economic, environmental, and social consequences. Cities and towns are complex spatial structures supported by transport systems, and automobility dominates many urban planning decisions. Such approaches to transportation and land use patterns favour and promote car use, providing inadequate alternatives or more sustainable modes of transport such as public transport, cycling, and walking. However, automobility is now deemed unsustainable, and moves toward more sustainable modes of transport are both necessary and essential to improving the quality of life for all citizens. This study seeks to determine levels of automobility thinking and attitudes to transportation in Galway, a small city on the west coast of Ireland, and provides an innovative, quantitative measure of reliance on this single mode of transport. Results indicate people who live in the city are not as car dependent as its rural hinterlands, although this is seldom reflected in local authority and regional transport approaches and decision-making.
\end{abstract}

Keywords: automobility; transportation; car dependency; car-centric; urban planning; sustainability; sustainable transport

\section{Introduction}

The world continues to experience unprecedented urban growth. An estimated 54.5 per cent of the global population now live in urban settlements, and by 2030 cities and towns are projected to house 60 per cent of peoples worldwide [1]. This enormous projected growth in urbanisation brings with it numerous challenges, one of which is an increase in transport related energy consumption and its negative economic, environmental, and social consequences. Transportation remains a major user of energy and consumer of the global petroleum stocks, in addition to creating air and noise pollution, significantly contributing to anthropogenic climate change through excessive carbon dioxide emissions [2]. These damaging environmental impacts, in addition to suburban sprawl, have increased over the past number of decades to a point where current patterns of urban mobility are deemed unsustainable [3,4]. While decarbonising transportation are perceived as more challenging compared to other sectors [5], there are increasing calls for the scientific community to strengthen its proclamations that contemporary societies remain fixated on inefficient and oil dependent mobility technologies [6]. Moreover, it is argued that transport planning is at crisis point and it underestimates the key challenges facing urban planners $[7,8]$. In particular, car-orientated transport policies have taken up significant time, effort, and money, and "the consequences of carrying on with the same old policies are grim" [9] (p. 16). 
This study seeks to investigate automobility practice and thinking with respect to people living in Galway, a city on the west coast of Ireland with a population of 79,504 [10]. With a significant additional population living in its immediate hinterlands, Galway is an ideal site for investigating issues of transport and liveability as these relate to small developing cities, towns, and urban/semi-rural settings. Such local studies are essential because transport has many detailed local dimensions which are often undertreated in the literature and can be thought of as existing transport cultures and practices. An innovative metric (henceforth known as the "Galway measure of automobility") to gauge levels of automobility in urban environs is provided. In addition to actual car usage for travel needs, this research also seeks to determine how deep car-centric thinking and automobility rationale is entrenched in the transport consciousness of people living in the city, who may view such practice as an inevitable consequence of growth and progress. Moreover, to embed such research in the realities and context of prevailing conditions and policy debates is essential thus; more detailed analysis and discussions with regards to local transport decisions and possible future direction is provided with the aim of providing a framework to further efforts toward sustainable transport policy design and decision-making. While such changes in transport management remain challenging, cars make disproportionately poor use of scare urban land and traffic and noise pollution, and indeed Galway's frequent congestion problems, make moves toward a sustainable transport future essential, practical, and timely.

\section{The Literature on Automobility}

The car has transformed social life, our environment, and communities over the past century in many significant ways. People spend ever-increasing periods of their lives travelling in cars and for many such car use is essential for all their needs. The automobile, it is argued, is the ultimate expression of consumption to satisfy the need for identity, autonomy, and individuality and this has become synonymous with notions of freedom [11]. In attempting to reach some systemic account to understand the complicated politics of cars, automobility emerged as the term which can best encapsulate this concept [12-15]. Automobility is a principal socio-technical institution through which modernity is organised and is a set of political institutions and practices which seek to organise while simultaneously regulating their many consequences [16]. Indeed, cars are merely part of a wider system which ranges from the roads to the many social institutions of automobility, embodying ideals of freedom, movement, autonomy, and progress:

Such a car system is an assemblage of different entities, only some of which are commodified and only some of which are discrete physical products. As such the car system displays a variation that is much more immediately socially shaped than the individual car. And arguably it is the car system, rather than the car itself, which really matters. To analyse just the car is as absurd or as limited as to analyse railways in terms of the steam engine alone [17] (pp. 1-2).

Automobility is neither socially necessary nor was its development inevitable, but having got established now seems difficult, if not impossible, to break away from [18]. It has become institutionally "locked-in" and difficult to reverse, and debates on automobility suggest a cultural dominance of the car that goes well beyond its collective status as a key artefact [19]. People's dependence on the car is multifaceted and strongly related to modern culture and lifestyle thus, changing people's transport behaviour is not a simple task. However, small changes might well tip the car system in a different direction; "changes that through their dynamic interdependence could provoke a shift beyond automobility" [20] (p. 27).

Automobility leads to transportation and land use patterns which favour, and indeed promote, car use, providing insufficient alternatives or sustainable modes of transport such as public transport, cycling and walking. In such cases, the design of cities and towns adapt primarily to the needs of the car in terms of movement and the allocation of space. Largely driven by such acceptance of the car 
as the primary source of transportation, suburban sprawl has also become a major feature of many cities and large towns in the developed world, including those in Ireland. Research suggests that even low density suburban sprawl is strongly related to high levels of car use and that urban form is the main determinant in relation to harmful emissions in cities [21]. In his acclaimed book Bowling Alone, Robert D Putnam [22] maintains that suburban sprawl has been a significant contributor to civic disengagement in communities' right across America over the last number of decades. People's everyday social and economic activities become linked to the private car both in practical terms and with regard to how they envisage their own mobility [23]. Indeed, elements of the automobility regime go far beyond a person's ability to exercise rational choice and beyond attitudinal and built environment factors [24].

In transport research and policy literature, use of the term "car dependency" is widespread. An over-reliance on the car should not be viewed merely as an issue of environmental sustainability due to the consumption of non-renewable resources and production of harmful greenhouse gases (GHGs) responsible for global warming; it is also an issue of economic and social sustainability. The negative consequences of car dependency include social exclusion and transport-related discrimination [25-27], the personal costs associated with running a car (the AA maintain that the average cost of running a family car in Ireland for 2016 was $€ 10,849.42$, an increase of over $€ 255$ since 2015) and the economic costs of traffic congestion $[28,29]$, in addition to its effect on public health and wellbeing [9,30] (for an extensive list of negative consequences, the key reference in the European Union for assessing the externalities of car dependency is the Handbook on estimation of external costs in the transport sector [31]). There is also mounting evidence of a link between excessive car travel and overweightness, and a reduction in driving may lead to the added benefit of reducing obesity rates in the developed and developing world [32-34]. While issues relating to cause and effect need to be explored and concerns such as the rapid proliferation of fast-food outlets and other elements of western diet, in addition to increased sedentary lifestyles, need attention, the evidence is quite clear: obesity is increasing worldwide in line with a rise in car use, while walking and cycling are generally in decline, and to this extent the car is markedly implicated in increasing weight gain [35].

In addition, it has been suggested there are similarities between tobacco and private cars in their influences on health. While tobacco harms individual smokers cars have greater negative externalities harming the wider community and global sustainability [36]. Car dependency, when combined with car-centric thinking and practice, build unacceptable levels of automobility but having significant damaging economic, social, and environmental impacts and consequences.

Remedial measures need to focus on reversing the preference for car use, shifting people toward public transport, cycling, or walking, and building and retrofitting cities to minimise the need for private automobiles. Sustainable mobility provides an alternative paradigm within which to investigate the complexity of cities, and to strengthen the links between land use and transport [37]. Possible sustainable mobility transitions have a need for both technological and institutional changes to achieve a radical reconfiguration of transport systems for sustainability [38]. Cities are shaped by their transport systems, and sustainable transport systems can make a positive contribution to the environmental, social and economic sustainability of cities, towns, and communities they serve. The way forward is a full and detailed consideration of alternative pathways to low-carbon mobility and a lot more of rethinking when it comes to the transport system and it's planning [39]. In Ireland, the lack of alternatives to the car, specifically accessible and reliable public transport and adequate cycling and walking facilities, has been suggested as one of the most significant barriers in terms of delivering sustainable transport at local level [40].

\section{Car Practice: A More Local Gaze}

Ireland has repeatedly been classified as one of the most car dependent European countries [41,42], and transport-related exclusion experienced by car-less rural and urban households remains a significant problem for the country $[7,41,43]$. Such levels has numerous impacts on society and the economy; 
increasing transportation costs for individuals and increasing resource consumption while requiring significant financial and land use capital. For instance, recent analysis found high net commuting costs as a percentage of income in Galway [44]. An over-reliance on the car stimulates increased traffic congestion in cities and towns with the associated roadway risk and environmental impacts reducing the viability of other travel modes, leading to more dispersed land use and mobility intensive economic patterns which require more travel for access [45]. In Ireland, the automobility regime has become locked-in in terms of institutional and policy responses. Social life has become linked to the mode of mobility which automobility both generates and presupposes and seems almost impossible to break or reverse [46]. Moreover, the broad orientation of transport policy in Ireland has remained relatively unchanged despite the roll-out of fiscal austerity measures as well as a change in government that was expected to bring a radical departure from previous policy thinking and practice [47]. In an Irish context, any discourse on the end of car-centric thinking and "predict and provide" approaches to transport infrastructure planning may well indeed be premature (the "predict and provide" response to traffic management has been to calculate future transport demand based on current figures and provide infrastructure and services to match that future demand [48]).

So, what evidence exists with regard to Ireland's high rates of car dependency, and how is this measured? The National Travel Survey (NTS) was conducted as a module of the Quarterly National Household Survey (QNHS) in the fourth quarter of 2014 and was an attempt to obtain information on people's day to day travel behaviours and to gain an understanding of their travel needs [49]. 70 per cent of respondents indicated that they travelled on the reference day, and almost three quarters of journeys (74.4\%) were by car, either as driver or passenger. Only 5.3 per cent were passenger car journeys with the vast majority $(69.1 \%)$ being car drivers on the day. The next most popular modal choice was walking (14.8\%). Those living in Dublin were less likely to drive than those in the rest of the country, largely due to population density and the broad availability of public transport (less than six out of ten journeys by Dubliners (58.1\%) were by car, compared to nearly three quarters of journeys by those living in the rest of the country $(73.9 \%)$ ).

Located on the west coast of Ireland, the combined Galway County area (made up of both the urban areas and significant rural hinterlands) largely reflects the trend of high car dependency for household travel outside of Dublin. Higher levels were detected in rural areas. A more recent report found high dependence on the car among personnel from the city and county travelling to work in the east of the city, with 77.9 per cent of people driving to work, 10.5 per cent taking the bus, 4 per cent cycling, and only 2.9 per cent walking [50]. Significantly, less than one per cent of people living in rural areas were found to travel to work in the east of the city by bus. An analysis of modal share at the National University of Ireland Galway indicated that the Galway campuses also have a heavy reliance on car usage [51]. The ability of people in the Galway region to reach their places of work is largely determined by their choice of residential location. In Ireland, public transport exists principally for urban dwellers and rural services are limited and largely unsupported leading to increased usage of the private car for all travel needs outside urban areas such as Galway and this is highly relevant to policy debates which link car dependency and excessive spatial mobility to time poverty, reduced quality of life, and a decline in citizen engagement and social capital [43].

While these studies of transportation in Galway would indicate high levels of car use, they are narrowly focussed on location-specific workers and students and actual travel mode choice. For instance, the Chamber of Commerce Travel Trends survey focussed exclusively on employees working in the large business parks to the east of the city (i.e., Parkmore, Ballybrit, and Mervue), and many of these workers come from across and, indeed, outside the city. While such studies are commendable in terms of understanding the travel behaviours of workers in these business parks, what is largely ignored are the people who live in these areas and deal with the consequences of increasing traffic, noise, and air pollution linked to the automobility regime. Moreover, efforts solely focussed on improving accessibility for car dependent workers to these areas by building more roads will have social, environmental and health consequences for residents in these areas and across the city. (Plans 
for a new road to alleviate traffic congestion at Parkmore have already been rejected by An Bord Pleanála in late 2016 after an initial local planning decision was appealed by a local resident and a representative of the Galway Cycling Campaign on road safety grounds).

\section{Research Method}

The data for this study was gathered as part of the overall Mobilities and Liveability in Galway research project, an innovative cooperative teacher/student study which sought to capture people's opinions, views and understanding of key issues related to transport and liveability in Galway, Ireland. (The positive effect on student learning through the inclusion of real-life, complex, and unstructured research-like activities is at the core of undergraduate education, and following this paradigm the student acts as "producer" of knowledge instead of simply knowledge consumer. The concept behind "student as producer" is that student learning is grounded in research and research-like activities so much of what the student learns will be through his or her own discoveries, working in collaboration with academic advisers and other students in a research-rich environment). Data collection was carried out by undergraduate research students from the School of Political Science \& Sociology at the National University of Ireland Galway over a five month period in 2016. The Mobilities and Liveability in Galway project was a quantitative study comprising of a questionnaire of 43 questions on issues related to transport, mobility and liveability, and eight demographic questions (a copy of the full questionnaire is available to download from http://ssrc.ie/docs/mobilities_\&_liveability_galway.pdf). The questions chosen were a result of much deliberation and were based on local transport debates and media discussions. For instance, the statement on traffic lights was directly linked to the recent transformation of key junctions in the city from large roundabouts to traffic light systems. This is has led to complaints of traffic delays in the city, particularly by car drivers. Other issues such as additional road building, parking, and attitudes toward cycling and bus lanes are all ongoing concerns for citizens, advocacy groups, the local media, and in decision-making circles.

A stratified probability sampling approach was employed with the urban population of the city broken into its three respective electoral districts; Galway City Central (24.96\%), Galway City East $(39.83 \%)$, and Galway City West (35.21\%). The current population of the city is 51.94 per cent female, 48.06 per cent male [10]. Data collection was initially carried out by the widespread localised promotion of the questionnaire via social media and made available through the free and open source online application LimeSurvey. Efforts at limiting digital biases were made; including avoiding the assistance of various local transport advocacy and lobby groups. Concerns about the asymmetry of responses and, indeed, the digital divide prompted researchers to limit online responses. Therefore, after the preliminary online collection phase the questionnaire was then administered through face-to-face approaches to residents in targeted areas of the city to satisfy the sampling method adopted. Attempts were made to limit, as far as possible, spatial biases by using a systematic sampling method of these selected areas. Over $400(n=416)$ fully completed questionnaires were gathered and 38 incomplete questionnaires; an overall total of $n=454$. The percentage breakdown of collected questionnaires were; Galway City Central (27.16\%, $n=113)$, Galway City East (38.70\%, $n=161)$, and Galway City West $(34.14 \%, n=142)$; and male $(45.90 \%)$ female $(54.10 \%)$. Further location-specific breakdown of participants is provided in the Appendix A. The data collection period ran from the 9 June 2016 to the 9 November 2016, at which point they were input into SPSS (IBM Corp. Released 2013. IBM SPSS Statistics for Windows, Version 22.0. Armonk, NY, USA) to enable data analysis. An interesting snapshot comparison (see Figures 1 and 2) between the 2011 CSO figures for Galway City, the most current available, and the findings from this particular study would suggest our sample is generally representative of the people living in Galway and how they travel to work or study. 


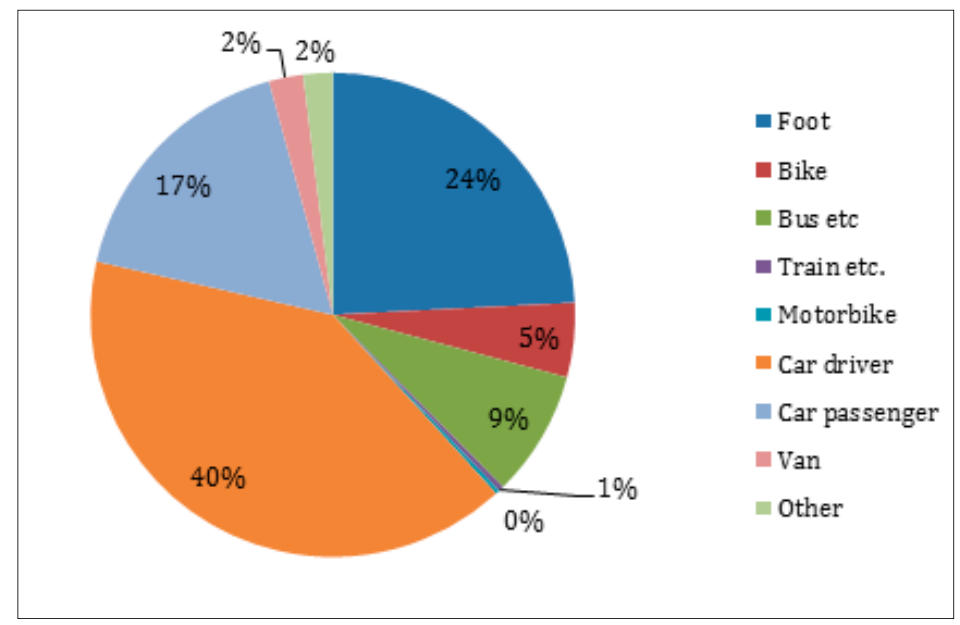

Figure 1. How people living in Galway travel to work [52].

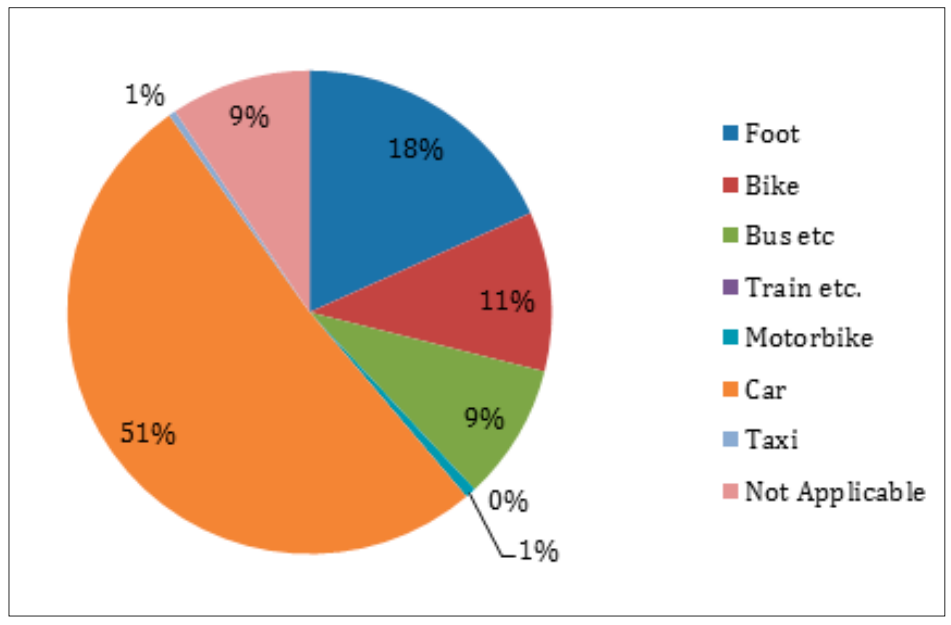

Figure 2. How people living in Galway travel to work (findings from our study).

\section{Car Sick?}

The car has had significant effects on the culture of many developed countries, including Ireland. The key focus of this paper is an attempt to measure, in some noteworthy manner, the dominance (or otherwise) of the car for the travel and mobility needs for people living in Galway, and their understanding and attitudes to urban transport planning and priorities. While many important surveys measure actual travel mode for particular activities, such as the commute to and from work, little is known about the embedded nature of automobility in people's consciousness. Understanding people's travel routines, practices, beliefs, and understanding, and how they change, is central to help plan more effective and sustainable transport systems and policies in the future. Such policies make an important contribution to tackling some of the big issues of the day including; energy security and climate change, public health and obesity, how to create healthy urban environments, and supporting economic growth and reducing traffic congestion. The car has been both flexible and coercive, and communities have become synchronised to the rhythms of the roads and car networks, producing a violence which interrupts and shapes the social environment [53]. The priority given to the car in general is itself driven by Western cultural values, and the automobile has come to dominate transport approaches, thinking, departments, and policy [54]. People have come to accept without question the need for additional road space to accommodate even more cars for example, and this system of organisation, rationality, and logic presupposed by the car becomes entrenched in transportation 
thinking. The ability of the car to go anywhere has been facilitated by such thinking and the building of roads, driveways and parking, at enormous cost to the community is borne by the public purse [55] (p. 25). This leads to urban policy designers and decision makers, often with the backing of popular opinion based on automobility regime bias, prioritising the movement of car traffic over other modes of transportation such as walking and cycling. Therefore, a deeper understanding of the extent of car-centric thinking, coupled with actual travel mode choice, is necessary.

As revealed earlier, the National Travel Survey [49] indicated a high national reliance on the car for commuting to and from work in Ireland, both as a driver and passenger. But people use the car for many other reasons, activities, and life events, and this study set about incorporating these additional personal and family activities and considerations to reach more meaningful findings about actual levels of automobility. In the questionnaire, individuals were asked how they travelled to; a corner shop, local school, a place to socialise, crèche or childcare facilities, shopping centre or supermarket, church or place of worship, to meet family and friends, and work or a place of study. In Figure 3 below, the results of these questions are provided in a series of descriptive statistical graphs in percent format. An interesting observation is that car use is highest for people traveling to shopping centres and supermarkets. Based on the author's experiences, in the case of Galway, such shopping centres are built to solely accommodate the car. There is limited public transport for shoppers at these centres (Buses may indeed stop in the vicinity of these Shopping Centres, but none enter the carpark or surrounding grounds to drop off or collect shoppers), little or no cycling stands or facilities (where these are provided they are in poor condition, open to the elements, and a distance away from the shopping centre entrance), and pedestrian walkways are limited, inadequate, and poorly maintained. Conversely, in all travel requirement instances, walking is a significant mode of travel for many people in all areas of the city, passenger journeys on the public transport network continues to increase [56], and cycling remains a viable option for between 5 to 11 percent of the population. This would suggest that, when offered a reasonable choice, a significant number of people choose sustainable transport alternatives to using the private car.

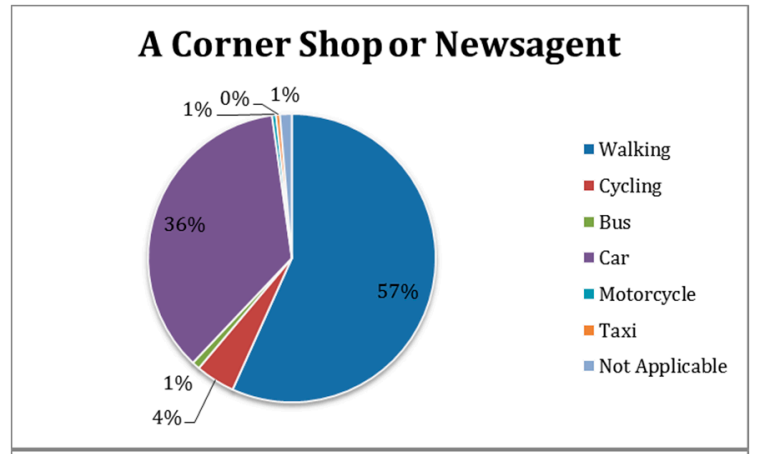

\section{A Place to Socialise (e.g. Pub or Community Centre)}

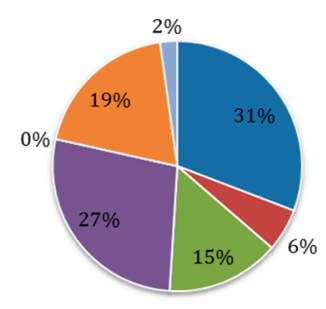

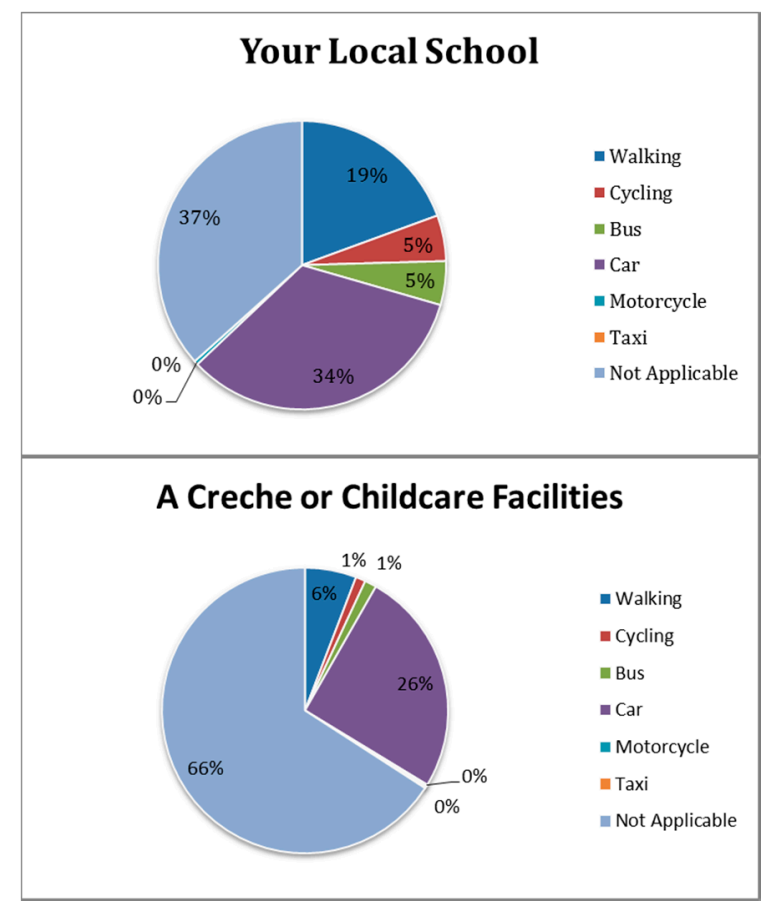

Figure 3. Cont. 


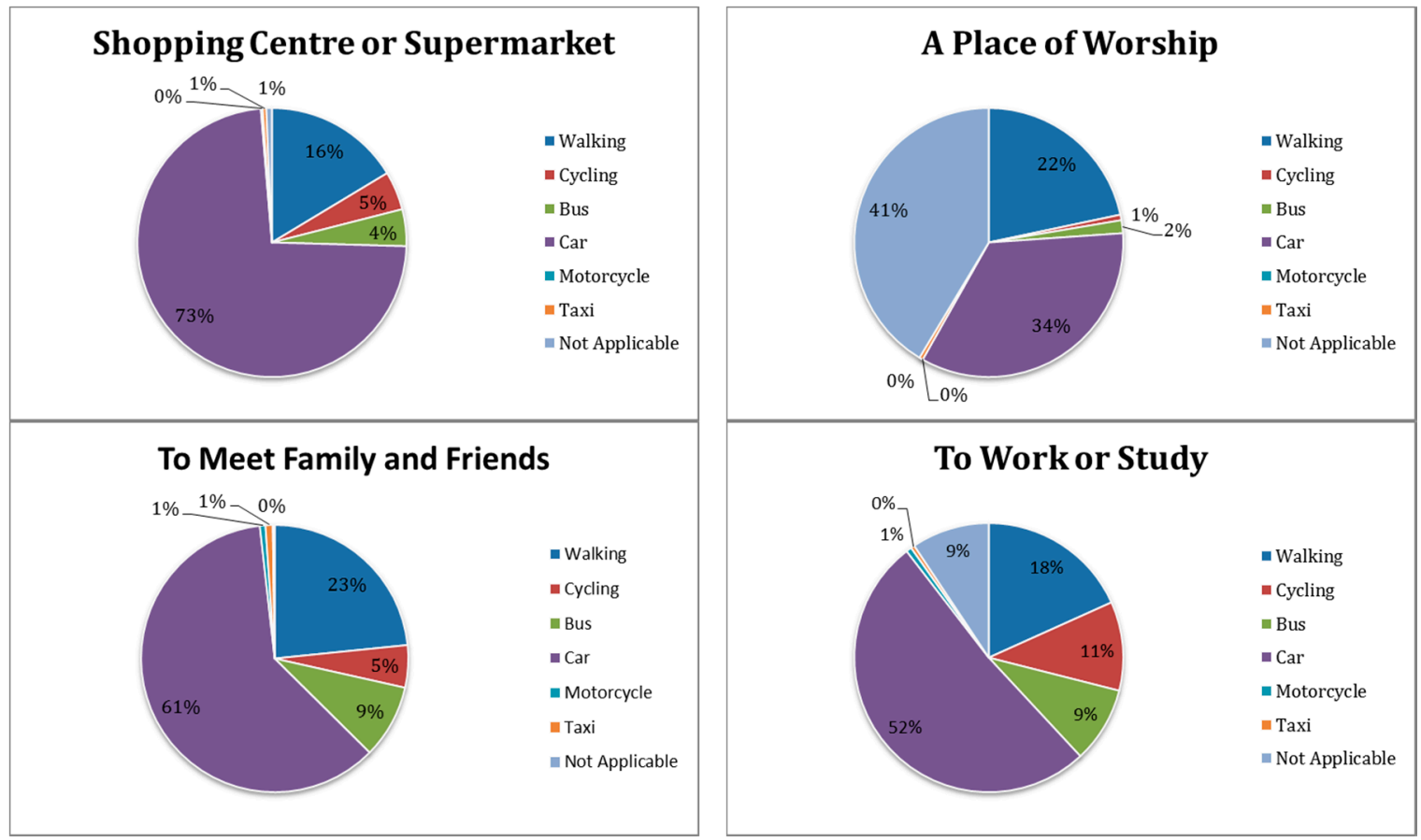

Figure 3. Results of self-reported mode of transport.

The Galway measure of automobility was developed as a systematic ranking of merged car dependency and car-centric thinking thus; we initially set about grading and scoring these modes of transport in each instance. Where people selected sustainable transport, i.e., walking, cycling, or the bus, or if a variable was not applicable (for instance, some individuals did not have children so entered "not applicable" to the question, "how do you usually travel to a crèche or childcare facilities?"), zero for this particular instance was recorded. If individuals used a motorcycle one point was recorded, a taxi was ranked at two points, and a private car at three points to reflect increased levels of automobility practice.

But, self-recorded actual travel behaviour often ignores the embedded and hidden nature of car-centric thinking, particular in how people view their local environment and urban transport planning decisions and concerns over liveability. (Liveability is defined as the sum of the factors which add up to a community's quality of life including the built and natural environments, economic prosperity, social stability and equity, educational opportunity, and cultural, entertainment and recreation possibilities). Therefore, another set of questions, based on local transport debates, were asked which focussed on particular issues related to the dominance of the automobility regime in urban planning design and decision-making to provide a deeper understanding of how people arrive at their attitudes and behaviours toward transport and mobility. The six questions and descriptive statistical results are provided in the graphs in Figure 4 below. 


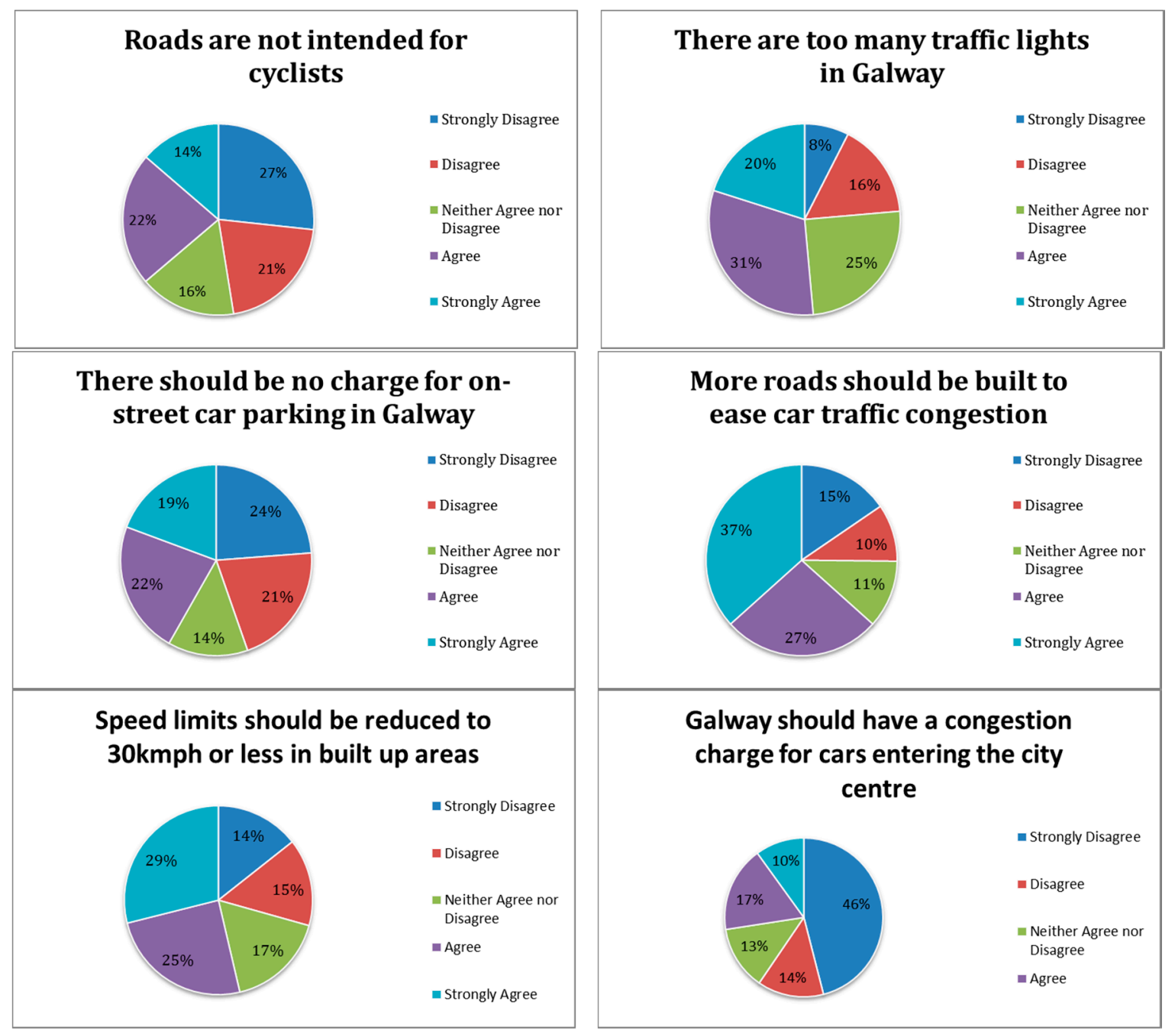

Figure 4. Results of embedded car-centric thinking.

Once again, these answers were ranked in order of automobility regime thinking with people who agreed with the first four questions given two points and strongly agreeing three points. This scoring was reversed for the subsequent two questions, reflecting sustainability rationale. Totals for all 12 questions were then calculated for each participant. The resultant Galway measure of automobility is provided in Figure 5, and outcomes were somewhat mixed. 12 people scored zero points, reflecting a strong contrary attitude to car-centric thinking and approaches to transport. Some 128 people (over $28 \%$ ) scored 10 points or less, again reflecting potential strong opposition to automobility in the city. With only one person scoring a high 41 out of 42 points, 52 individuals scored 30 points or more, approximately 11.5 per cent of respondents. This particular grouping would, it suggests, be advocates of the automobility regime for travel needs and promoters of increased planning and investment in support of car use in Galway. Transportation for this grouping can be said to be largely reflective of car-centric thinking where the automobile dominates transport planning and their understanding of urban design, mobility, and liveability. The remainder of participants $(60 \%)$ scored between 11 and 29 points suggesting varying levels and degrees of behaviours and thinking amongst individuals from right across the city. While these figures would appear diverse, they do point to some interesting realities about how people view transportation in Galway, providing important understandings and direction for policy makers, urban designers, politicians, and other key decision makers. 


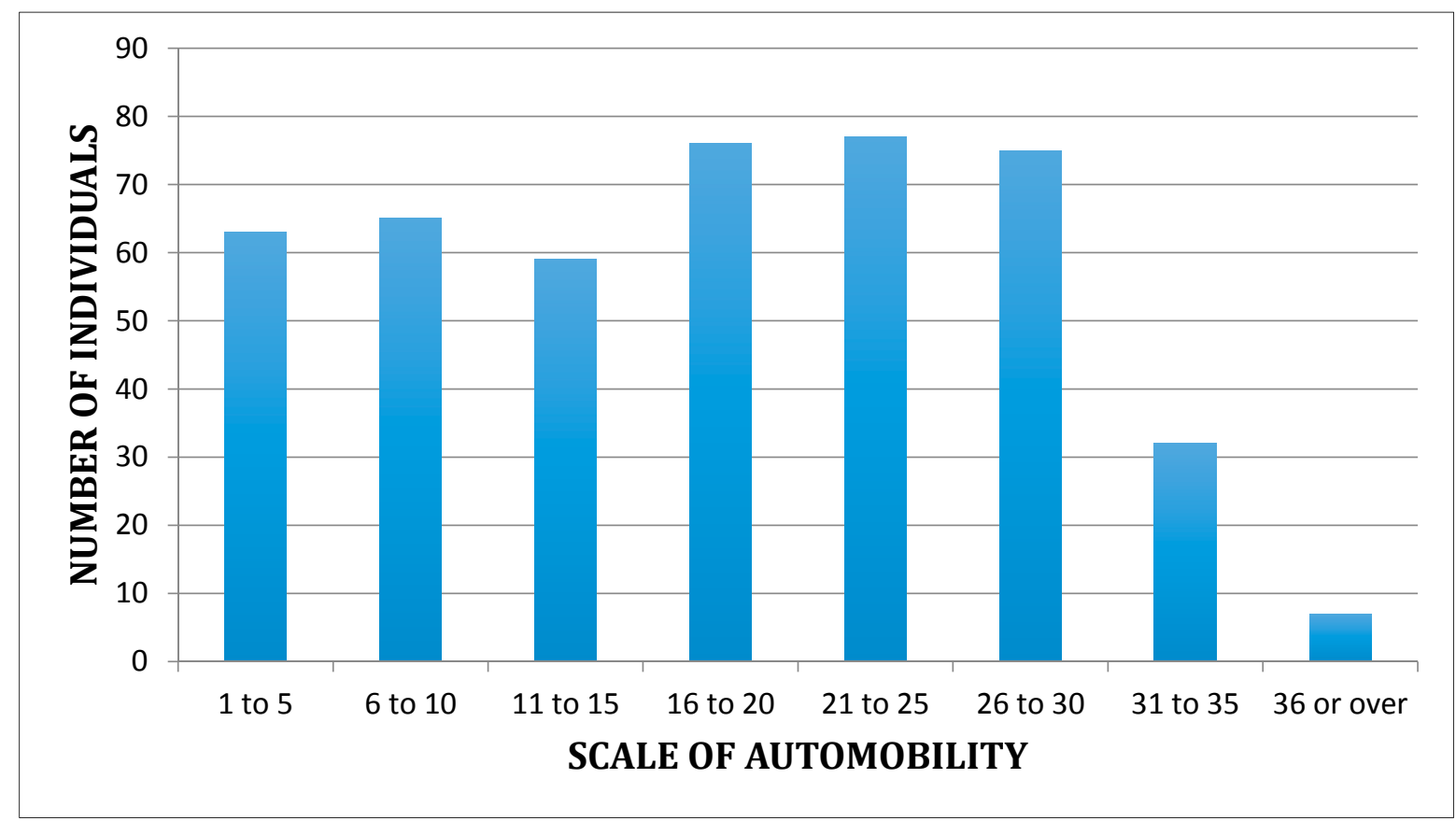

Figure 5. Automobility in Galway.

In some further analysis of the data, minor difference was detected between the various transport modes used to get to work or study and levels of self-reported happiness. 78 per cent of individuals who walked, 79.2 per cent of cyclists, 82.9 per cent of people who used the public bus system, and 81.8 per cent who used a private car claimed they were somewhat happy or very happy. Levels of self-reported health revealed that 78 per cent of people who walked, 89.6 per cent of cyclists, 78 per cent of public transport users, and 81.4 per cent of private car users were in good or excellent health. When asked if they had the use of a bicycle, 51.2 per cent of walker, 56.1 per cent of public transport users, and 47.6 per cent of private car users reported that they did not own or have use of a bicycle. Respondents were also asked if there was public transport available for their commute to work or college. Results indicate that 76.8 per cent of walkers, 79.2 per cent of cyclists, and only 55.8 per cent of car users indicated that public transport was available for their commute. This could be understood in both a negative or positive manner. It would indicate that over 44 per cent of car users do not have this transport option available to them, suggestive of a public transport deficient for Galway commuters. Alternatively, and on a more positive note, 55.8 per cent of current car users have such a transport choice for their daily commute to work or study and thus are open to be incentivised or persuaded to change to public transport use.

\section{Discussion: How Findings Relate to Prevailing Local and Regional Transport Considerations}

While high levels of automobility regime rationale and car use were anticipated, the results do not quiet bear out such findings, particularly relative to the high levels of car use recorded in the CSO national figures. This study suggests that people's understanding and decision-making on issues related to transport and liveability in Galway is far more progressive and multifaceted than previously acknowledged. It reveals that while the car is seen as part of the fabric of the city, at present, it is far from the excessively dominant transport choice with many residents opting for sustainable alternatives such as walking, cycling, and public transport for various activities and, family and life events. Such findings reveal a crucial "window of opportunity" for a more positive move toward sustainability with regard to mobility, transport, and liveability in Galway. There are a number of directions to go when we find ourselves at a crossroads, and contextualising the finding by discussing local transportation debates is beneficial in selecting the best route. 
Are politicians and policy designers making transportation and planning decisions largely to cater for workers from outside the city, and are the mobility and liveability needs of dwellers in the city being marginalised or ignored? If so, with such decision-making the human dimension of liveability in the Galway is being overlooked and "such planning ideologies put a low priority on public space, pedestrianism and the role of city space as a meeting place for urban dwellers" [57] (p. 3). While the economic base of the city is dependent on workers travelling into the city to work, the quality of life and aspects of liveability for people choosing to live in the city is being surrendered to unsustainable road building which, as continuing evidence shows, damages communities [58,59]. To reduce our dependence on the car and cut congestion, road policies in cities should be focussed on demand management not on increasing capacity for car travel which merely creates more traffic and more congestion [60]. In her book The Death and Life of the Great American Cities, written in the early 1960s, the writer Jane Jacobs maintained:

The simple needs of automobiles are more easily understood and satisfied than the complex needs of cities, and a growing number of planners and designers have come to believe that if they can only solve the problems of traffic, they will thereby have solved the major problem of cities. Cities have much more intricate economic and social concerns than automobile traffic. How can you know what to try with traffic until you know how the city itself works, and what else it needs to do with its streets? You can't [61] (p. 4).

There are signs of a weakening of automobility regime thinking in urban planning and development worldwide and a growing acceptance of a transport sustainability agenda within industry, governments, the academic community, and general public [62]. Indeed, in 2009 the Irish Government maintained that Irelands transport policies and decisions relating to the automobility regime are largely unsustainable [63]. However, decision makers and policy advocates in Galway and surrounding regions continue to embrace "predict and provide" approaches in their attempts to ease congestion in and around the city. Since 1999, Galway City Council and Galway County Council have strongly backed the construction of the N6 Galway City Outer Bypass in attempting to develop solutions to the existing transportation issues in Galway City and its environs. The most recent estimate suggests the new ring road will cost nearly $€ 600$ million to construct, and result in the destruction of nearly 50 homes [64]. While it must be recognised both councils also maintain that any transportation solution must include a related smart mobility and public transport component; these elements are predicated on the construction of the new ring road. But more road space simply means more cars and more congestion in the longer term.

In economics, induced demand is the general principle that when the supply of a product increases demand for it will also increase. This principle also applies to transportation and has been recognised by road traffic professionals for many decades as a driver of additional traffic, also termed "generated traffic" [65-68]. (Generated traffic has a number of implications for transport planning. It diminishes the congestion reduction benefits of road capacity expansion. It also increases many external costs and, it provides relatively small user benefits because it consists of vehicle travel which consumers are most willing to forego when their costs increase). While a new road may provide motorists with some level of respite from congestion in the short term, almost all of the benefit from the road will be lost in the longer term. Indeed, improvements in, and additions to, the overall road network can make congestion worse if these improvements make public transport more inconvenient, walking and cycling more dangerous, or if it shifts support causing disinvestment in these sustainable modes of transport. (Also known as the Downs-Thomson paradox, it shows that some measures meant to improve a commute actually result in slower trips for everyone). Bypasses generate traffic and produce additional congestion, partly by inducing people to travel who would not otherwise have done so by making the new route more convenient than the old, partly by people who go out of their direct route to enjoy the greater convenience of the new road, and partly by people who use the towns bypassed because they are more convenient for shopping and visits when through traffic has been removed [65]. 
The "fundamental law of road congestion" proposes that the extension of major road networks is met with a proportional increase in traffic [69].

With significant and growing numbers of residents of Galway opting for sustainable modes of transport for work, study, and personal and family activities, this emphasis on road building as part solution to congestion will lead to increased car traffic and congestion and decreasing numbers electing to walk, cycle, or use public transport. Any hard-earned gains toward sustainability achieved over the recent past are likely to be undone given the prioritising of the practice and ideology of automobility over sustainable modes of transport. As many cities throughout Europe, including Dublin, strive to reverse the destructive impact of car-centric policies and actions (Urban planners and policy makers around the world have started to brainstorm ways that cities can create more space for pedestrians and lower $\mathrm{CO}_{2}$ emissions. This has led many cities to plan for car-free and more pedestrian-friendly urban areas [70]), Galway remains on a trajectory which bucks trends of best practice by building and providing even more road space for cars. But, as this study suggests, and given the geographical compact nature of Galway; innovative, healthy, sustainable, and low cost alternatives to the dominance of the automobility regime will attract support and win over critical mass over time. It does appear Galway is, indeed, at a crucial crossroads.

\section{Conclusions}

As urbanisation intensifies globally, issues related to mobility and transport continue to challenge policy and decision makers in cities and towns across the developed and developing worlds. High levels of automobility are most acute when car use is favoured over other and more sustainable, modes of travel in transportation policy and urban planning and design. The automobility regime prioritises the car over the human and social dimensions. This study set out to primarily provide a metric of how the dominance of automobility policy and thinking can be evaluated. Using a novel set of questions, the Galway measure of automobility sought to determine how often people use their car for their daily activities, in addition to evaluating how deep car-centric thinking and consequential transportation rationale is embedded. Such a metric should be iteratively developed and built upon, and used to establish levels of automobility in other cities, towns, and urban settlements. Results from this study would suggest that many people in Galway are not as wholly car dependent as county-wide CSO figures would suggest, and people choose a range of alternatives depending on their specific needs and activities. Moreover, individuals have an enlightened and nuanced understanding of transportation issues which are seldom articulated by local politicians, urban planners, and key decision makers in the region. This offers an important "window of opportunity" to effect real and positive change with regards to sustainability in the context of transport, mobility, and liveability in the city.

The metric offered in this study is an early iteration in the development of a more robust metric for understanding levels of automobility. The questions asked were locally focussed and culturally specific to Galway, but there is need to link local automobility rationale with actual travel behaviours to obtain deeper understandings of its effects and consequences on transportation and urban design, planning, and decision-making. It is recommended that much more emphasis be placed on research into the holistic nature of automobility behaviours and practices, with an ultimate aim of better understanding the pressure and barriers which exist to move toward more sustainable transportation practices and behaviours. Additional research, with a stronger focus on the people who have elected to live and invest their futures in cities, is both desirable and essential to build an enhanced understanding of many of these crucial contemporary urban issues.

Acknowledgments: The author wishes to acknowledge the assistance of student researchers Olga Bolbocean, Dylan Chambers, Emer Coyne, Stephen Doyle, Eliona Gjecaj, Gerard Molloy, Evelyn Nicola Murtagh, Eibhlín Seoighithe, and Patrick Gerard Treanor. In addition, the support of the Social Sciences Research Centre (SSRC) at the National University of Ireland Galway has been invaluable. The author also wishes to recognise and acknowledge all the participants and contributors to this research and thank them for their time, effort, and generosity. 
Conflicts of Interest: The author declares no conflict of interest.

\section{Appendix A}

\begin{tabular}{|c|c|c|}
\hline Specific Residential Area of the City & Number of Responses & Electoral Areas \\
\hline Ballybane & 14 & Galway City East \\
\hline Ballybrit & 14 & Galway City East \\
\hline Ballinfoyle & 11 & Galway City Central \\
\hline Barna & 8 & Galway City West \\
\hline Briarhill & 10 & Galway City East \\
\hline Bushypark & 3 & Galway City Central \\
\hline Castlegar & 5 & Galway City East \\
\hline City Centre/Bohermore & 10 & Galway City Central \\
\hline Claddagh & 11 & Galway City West \\
\hline Dangan & 5 & Galway City Central \\
\hline Doughiska & 23 & Galway City East \\
\hline Knocknacarra * & 79 & Galway City West \\
\hline Menlo & 19 & Galway City East \\
\hline Mervue & 14 & Galway City East \\
\hline Murrough & 5 & Galway City East \\
\hline Newcastle & 16 & Galway City Central \\
\hline Rahoon/Westside & 26 & Galway City Central \\
\hline Renmore & 29 & Galway City East \\
\hline Roscam & 13 & Galway City East \\
\hline Salthill & 34 & Galway City West \\
\hline Shantalla & 17 & Galway City Central \\
\hline Taylors Hill & 10 & Galway City West \\
\hline Terryland & 20 & Galway City Central \\
\hline Tirellan & 5 & Galway City Central \\
\hline Tuam Road & 7 & Galway City East \\
\hline Wellpark & 8 & Galway City East \\
\hline Unknown & 38 & \\
\hline Total & 454 & \\
\hline
\end{tabular}

* Knocknacarra is the most densely populated area of the city (see http://galwaydashboard.ie/electoral-divisions).

\section{References}

1. United Nations. The World's Cities in 2016; Economic and Social Affairs, United Nations: New York, NY, USA, 2016. Available online: http:/ /www.un.org/en/development/desa/population/publications/pdf/ urbanization/the_worlds_cities_in_2016_data_booklet.pdf (accessed on 10 April 2017).

2. Intergovernmental Panel on Climate Change (IPCC). Climate Change 2014: Mitigation of Climate Change; Contribution of Working Group III to the Fifth Assessment Report of the Intergovernmental Panel on Climate Change; Cambridge University Press: Cambridge, UK; New York, NY, USA, 2015.

3. Environmental Protection Agency (EPA). Ireland's Greenhouse Gas Emission Projections 2014-2035; Environmental Protection Agency: Wexford, Ireland, 2015.

4. Hickman, R.; Banister, D. Transport, Climate Change and the City; Routledge: Abingdon, UK, 2014.

5. Creutzig, F.; Jochem, P.; Edelenbosch, O.Y.; Mattauch, L.; van Vuuren, D.P.; McCollum, D.; Minx, J. Transport: A roadblock to climate change mitigation? Science 2015, 350, 911-912. [CrossRef] [PubMed]

6. Jochem, P.; Rothengatter, W.; Schade, W. Climate change and transport. Transp. Res. Part D Transp. Environ. 2016, 45, 1-3. [CrossRef]

7. Wickham, J. Gridlock: Dublin's Transport Crisis and the Future of the City; New Island Books: Dublin, Ireland, 2006.

8. Banister, D. Unsustainable Transport: City Transport in the New Century; Routledge: London, UK, 2005.

9. Sloman, L. Car Sick: Solutions for Our Car-Addicted Culture; Green Books Ltd.: Devon, UK, 2006.

10. CSO Population and Actual and Percentage Change 2011 to 2016 by Sex, Province County or City, Census Year and Statistics. Available online: http:/ / www.cso.ie/en/releasesandpublications/ep/p-cpr/ censusofpopulation2016-preliminaryresults/geochan/ (accessed on 12 April 2017). 
11. Gartman, D. Three Ages of the Automobile: The Cultural Logics of the Car. Theory Cult. Soc. 2004, 21, 169-195. [CrossRef]

12. Urry, J. Sociology Beyond Societies: Mobilities for the Twenty-First Century; Routledge: London, UK, 2000.

13. Rajan, S.C. The Enigma of Automobility: Democratic Politics and Pollution Control; University of Pittsburgh Press: Pittsburgh, PA, USA, 1996.

14. Beckmann, J. Automobility-A Social Problem and Theoretical Concept. Environ. Plan. D Soc. Space 2001, 19, 593-607. [CrossRef]

15. Paterson, M. Automobile Politics: Ecology and Cultural Political Economy; Cambridge University Press: Cambridge, UK, 2007.

16. Bohm, S.; Jones, C.; Land, C.; Paterson, M. Against Automobility; Blackwell Publishing Ltd.: Oxford, UK, 2006.

17. Wickham, J.; Lohan, M. The Transport Rich and the Transport Poor: Car dependency and social class in four European cities. In Urbanism and Suburbanism at the End of the Century; National University of Ireland: Maynooth, Ireland, 1999.

18. Urry, J. Mobilities; Polity Press: Cambridge, UK, 2007.

19. Latimer, J.; Munro, R. Driving the Social. In Against Automobility; Bohm, S., Jones, C., Land, C., Paterson, M., Eds.; Blackwell Publishing Ltd.: Oxford, UK, 2006; Volume 54, pp. 32-53.

20. Urry, J. The 'System' of Automobility. Theory Cult. Soc. 2004, 21, 25-39. [CrossRef]

21. Newman, P.; Kenworthy, J. Sustainability and Cities: Overcoming Automobile Dependence; Island Press: Washington, WA, USA, 1999.

22. Putnam, R.D. Bowling Alone: The Collapse and Revival of American Community; Simon and Schuster: New York, NY, USA, 2001.

23. Rau, H. Environmental Arguing at a Crossroads? Cultural Diversity in Irish Transport Planning. In Environmental Argument and Cultural Difference: Locations, Fractures and Deliberations; Edmondson, R., Rau, H., Eds.; Peter Lang: Oxford, UK, 2008; pp. 95-124.

24. Mattioli, G.; Anable, J.; Vrotsou, K. Car dependent practices: Findings from a sequence pattern mining study of UK time use data. Transp. Res. Part A Policy Pract. 2016, 89, 56-72. [CrossRef]

25. Mattioli, G. Where sustainable transport and social exclusion meet: Households without cars and car dependence in Great Britain. J. Environ. Policy Plan. 2014, 16, 379-400. [CrossRef]

26. Hine, J.; Mitchell, F. Better for Everyone? Travel Experiences and Transport Exclusion. Urban Stud. 2001, 38, 319-332. [CrossRef]

27. Sustainable Development Commission. Fairness in a Car dependent Society; Sustainable Development Commission: London, UK, 2011.

28. The Economist. The Cost of Traffic Jams. Available online: http://www.economist.com/blogs/economistexplains/2014/11/economist-explains-1 (accessed on 15 March 2017).

29. Goodwin, P.B. The Economic Costs of Road Traffic Congestion; UCL (University College London), The Rail Freight Group: London, UK, 2004.

30. Kirby, T. Tackling Obesity in Cities. Lancet Diabetes Endocrinol. 2013, 1, s1-s2. [CrossRef]

31. Maibach, M.; Schreyer, C.; Sutter, D.; van Essen, H.; Boon, B.; Smokers, R.; Schroten, A.; Doll, C.; Pawlowska, B.; Bak, M. Handbook on Estimation of External Costs in the Transport Sector; CE Delft, Solutions for Environment, Economy and Technology: Delft, The Netherlands, 2008.

32. Sugiyama, T.; Ding, D.; Owen, N. Commuting by car: Weight gain among physically active adults. Am. J. Prev. Med. 2013, 44, 169-173. [CrossRef] [PubMed]

33. Jacobson, S.H.; King, D.M.; Yuan, R. A note on the relationship between obesity and driving. Transp. Policy 2011, 18, 772-776. [CrossRef]

34. Berg, N. Longer Commute, Bigger Waistline. Available online: http://www.citylab.com/commute/2012/ 05/longer-commute-bigger-waistline/1952/ (accessed on 13 March 2017).

35. Stopher, P.; Stanley, J. Introduction to Transport Policy: A Public Policy View; Edward Elgar: Cheltenham, UK, 2014.

36. Douglas, M.J.; Watkins, S.J.; Gorman, D.R.; Higgins, M. Are cars the new tobacco? J. Public Health 2011, 33, 160-169. [CrossRef] [PubMed]

37. Banister, D. The Sustainable Mobility Paradigm. Transp. Policy 2008, 15, 73-80. [CrossRef] 
38. Kemp, R.; Rotmans, J. Managing the Transition to Sustainable Mobility. In System Innovation and the Transition to Sustainability: Theory, Evidence and Policy; Elzen, B., Geels, F.W., Green, K., Eds.; Edward Elgar Publishers: Camberley, UK, 2004; pp. 137-167.

39. Banister, D.; Givoni, M.; Macmillen, J.; Schwanen, T. Thinking Change and Changing Thinking. In Moving Toward Low Carbon Mobility; Givoni, M., Banister, D., Eds.; Edward Elgar: Cheltenham, UK; pp. 267-283.

40. Browne, D.; Caulfield, B.; O'Mahony, M. Assessing the Barriers to Sustainable Transport in Ireland; Prepared for the Environmental Protection Agency; Trinity College Dublin: Dublin, Ireland, 2011.

41. Commins, N.; Nolan, A. Car Ownership and Mode of Transport to Work in Ireland. Econ. Soc. Rev. 2010, 41, $43-75$.

42. Campaign for Better Transport. Car Dependency Scorecard 2011: The Top European Cities for Sustainable Transport; Campaign for Better Transport: London, UK, 2011.

43. Rau, H.; Vega, A. Spatial (Im)mobility and Accessibility in Ireland: Implications for Transport Policy. Growth Chang. 2012, 43, 667-697. [CrossRef]

44. Vega, A.; Kilgarriff, P.; O’Donoghue, C.; Morrissey, K. The Spatial Impact of Commuting on Income: A Spatial Microsimulation Approach. Appl. Spat. Anal. Policy 2016. [CrossRef]

45. Litman, T.; Laube, F. Automobile Dependency and Economic Development; Victoria Transport Policy Institute: Victoria, BC, Canada, 2002.

46. Kingsley, D.; Urry, J. After the Car; Polity Press: Cambridge, UK, 2009.

47. Rau, H.; Hynes, M.; Heisserer, B. Transport policy and governance in turbulent times: Evidence from Ireland. Case Stud. Transp. Policy 2016, 4, 45-56. [CrossRef]

48. Vigar, G. The Politics of Mobility: Transport, the Environment, and Public Policy; Spon Press: London, UK, 2002.

49. Central Statistic Office (CSO). The National Travel Survey (NTS). Available online: http://www.cso.ie/en/ releasesandpublications/ep/p-nts/nationaltravelsurvey2014/ (accessed on 24 August 2016).

50. Galway Chamber of Commerce. Travel Trends to Galway City Business Parks; Traffic and Transportation Committee of Galway Chamber of Commerce in conjunction with Civil Engineering, NUI Galway: Galway, Ireland, 2016.

51. Fleming, M.; Manton, R.; Clifford, E. Designing for sustainable transport on campuses: A study of the effects of infrastructural improvements on travel patterns at NUI Galway and other institutions. In Proceedings of the ITRN Conference, Limerick, Ireland, 4-5 September 2014; Irish Transport Research Network: Limerick, Ireland, 2014.

52. Census 2011 Profile 10 Door to Door-Commuting in Ireland. Available online: http://www.cso.ie/ en/media/csoie/census/documents/census2011profile10/Profile_10_Full_Document.pdf (accessed on 25 March 2017).

53. Sheller, M.; Urry, J. The City and the Car. Int. J. Urban Reg. Res. 2000, 24, 737-757. [CrossRef]

54. Davison, G. Car Wars: How the Car Won Our Hearts and Conquered Our Cities; Allen \& Unwin: Sydney, Australia, 2004.

55. Redshaw, S. The Company of Cars: Driving as a Social and Cultural Practice; Ashgate Publishing, Ltd.: Aldershot, UK, 2012.

56. Bus Éireann Passenger Journeys up 230,000 on Bus Éireann Galway City Network in 2016. Available online: http:/ / www.buseireann.ie/news.php?id=2222\&month=Dec (accessed on 5 April 2017).

57. Gehl, J. Cities for People; Island Press: Washington, WA, USA, 2010.

58. Cahill, M. Transport Environment and Society; Open University Press: Maidenhead, UK, 2010.

59. Appleyard, D.; Gerson, M.S.; Lintell, M. Livable Streets; University of California Press: Berkley, CA, USA, 1982.

60. Campaign for Better Transport. Car Dependency Scorecard 2014: The Top English Cities for Sustainable Transport; Campaign for Better Transport: London, UK, 2014.

61. Jacobs, J. The Death and Life of Great American Cities; Random House: New York, NY, USA, 1961.

62. Newman, P.; Kenworthy, J. The End of Automobile Dependence: How Cities Are Moving Beyond Car-Based Planning; Island Press: Washington, WA, USA, 2015.

63. Department of Transport, Tourism and Sport (DTTAS). Smarter Travel: A Sustainable Transport Future. A New Transport Policy for Ireland 2009-2020; Department of Transport, Tourism and Sport: Dublin, Ireland, 2009.

64. Cunningham, E. Major revisions made to $€ 600 \mathrm{~m}$ outer bypass plans. The Connacht Tribune, 16 December 2016.

65. Leeming, J.J.; Mackay, G. Road Accidents: Prevent Or Punish? Cassell: London, UK, 1969. 
66. Goodwin, P.B. Empirical evidence on induced traffic: A review and synthesis. Transportation 1996, 23, 35-54. [CrossRef]

67. Duranton, G.; Turner, M.A. The fundamental law of road congestion: Evidence from US cities. Am. Econ. Rev. 2011, 101, 2616-2652. [CrossRef]

68. Litman, T. Generated Traffic and Induced Travel: Implications for Transport Planning; Victoria Transport Policy Institute: Victoria, BC, Canada, 2017.

69. Duranton, G.; Turner, M.A. The Fundamental Law of Road Congestion: Evidence from US Cities; Working Paper 370; National Bureau of Economic Research: Toronto, ON, Canada, 2009.

70. Garfield, L. 10 cities that are starting to go car-free. Business Insider, 16 August 2016.

(C) 2017 by the author. Licensee MDPI, Basel, Switzerland. This article is an open access article distributed under the terms and conditions of the Creative Commons Attribution (CC BY) license (http://creativecommons.org/licenses/by/4.0/). 